\title{
Evaluation of the Chemo-Radiotherapy Effect on the Level of Expression of miR-374 Gene Expression in Rectal Cancer Samples
}

\section{Azam Ahmadi}

Arak University of Medical Sciences

Mohamd Reza Bayatiani

Arak University of Medical Sciences

Fatemeh Seif ( $\square$ sahar_s59@yahoo.com )

Arak University of Medical Sciences https://orcid.org/0000-0002-1532-293X

Jamshid Ansari

Arak University of Medical Sciences

\section{Parisa Rashidi}

Arak University of Medical Sciences

\section{Mona Moghadasi}

Arak University of Medical Sciences

\section{Mobarake Etemadi}

Arak University of Medical Sciences

\section{Keywords:}

Posted Date: August 28th, 2020

DOI: https://doi.org/10.21203/rs.3.rs-57268/v1

License: (1) (i) This work is licensed under a Creative Commons Attribution 4.0 International License. Read Full License 


\section{Abstract}

The authors have requested that this preprint be removed from Research Square. 